\title{
"I can't enjoy my studies, I'm stressed" Effect of Academic Stress on Positive Mental Health In Students College
}

\author{
${ }^{1,2}$ Herdian, ${ }^{1}$ Totok Haryanto \\ ${ }^{1}$ Universitas Muhammadiyah Purwokerto, Indonesia. \\ ${ }^{2}$ Nanjing Normal University, China.
}

\begin{abstract}
The world has experienced a tremendous impact over the past two years due to the COVID-19 pandemic. One of the impacts is the change in the learning system from offline classes to online classes. Not a few studies say that online learning impacts students' psychology, one of which is academic stress. This study examines the effect of academic stress on positive mental health in college students during the COVID-19 pandemic. A total of 76 psychology students in Central Java, Indonesia, participated in this study. The results show a significant effect of academic stress on positive mental health in students during online learning during the COVID-19 pandemic. The implications of the results of this study are discussed in detail.
\end{abstract}

Keywords: Academic Stress, Positive mental health, student college, pandemic COVID-19

\section{Introduction}

The COVID-19 pandemic that has occurred worldwide is an extraordinary event that affects many aspects of life. Previous research has empirically proven its impact on aspects of education (Aji, 2020), economy (Nasution et al., 2020), tourism (Sugihamretha, 2020), agriculture (Ulya, 2020), to the workforce (Syahrial, 2020). One of the most significant impacts is on aspects of education worldwide. The COVID-19 pandemic has impacted school closures worldwide to anticipate the spread of the virus. Since March 2020, the school closure policy in Indonesia has been implemented simultaneously in all regions. As of the time this paper was written, it has been 21 months or almost two years since the school implemented distance learning with an online system.

However, the implementation of distance learning or online learning raises new problems for the effectiveness of teaching and learning. As reported by research results that say online learning is ineffective for early childhood education (Nurdin \& Anhusadar, 2020), some schools continue to use face-to-face learning. The results of other studies also provide an overview of how teachers perceive online learning, such as inadequate telecommunication facilities, low internet access, unfamiliar with online, unable to prepare and use learning materials effectively. Even training facilitated by schools is still considered insufficient (Sipayung et al., 2021). So that not a few say that students do not like online learning (Nugroho et al., 2020). It can be concluded that online learning conducted during the COVID-19 pandemic cannot run smoothly in all regions in Indonesia.

On the other hand, changes in online learning cause other problems such as academic stress. The results of Argaheni's research (2020) conclude that the ineffectiveness of implementing online learning impacts stress for students. Confirmed by Herdian \& Mildaeni (2021) research results, which examined academic stress on 731 students, the study results said that academic stress on students was in the moderate category as much as $69 \%$ and high $16.3 \%$. Another study said that students felt quite heavy pressure while carrying out online learning during the Covid19 pandemic (Lubis et al., 2021). Other studies also report that online learning affects academic stress during the COVID-19 pandemic (Andiarna \& Kusumawati, 2020). A study said that college students' highest percentage of stress was their uncertainty over semester final exams and 
assessments (Moawad, 2020). This can be caused by many factors, one of which is the increasing number of tasks during online learning (Masitoh, 2020).

Stress occurs when individuals cannot meet the demands of the environment (Lazarus \& Folkman, 1984). Stress in individuals can appear in many settings, such as school. The term often used to describe the stress in school settings is academic stress (Calaguas, 2011). Academic stress is when a person cannot face academic demands and perceives demands accepted as a distraction (Barseli et al., 2017). Academic stress is the main stress felt by students (Deroma et al., 2009; Guo et al., 2011).

Academic stress that occurs in students can affect their positive mental health. Positive mental health is a state of well-being where individuals realize their abilities, cope with life stresses, work productively, and contribute to their community (World health organization, 2018). There are six main approaches to describe the individual's positive mental health as a subject, including the individual's attitude towards himself, the extent to which people realize their potential through action; The unification of functions in the individual's personality, the degree of individual independence from social influences, how the individual sees the world around him and the ability to accept life as it is and master it (Jahoda, 1958). Positive mental health has a concept that includes positive emotions and behaviors, including well-being and feelings of happiness (Barry, 2009).

Referring to the state of academic stress, then this situation will affect their happiness. So that students cannot maximize their learning which is done online. This study examines the effect of each dimension of academic stress, including teacher stress, result stress, stress tests, a study in groups stress, peer stress, time management stress, and self-inflicted stress on positive mental health.

\section{Materials and Methods}

This study uses a quantitative approach. The total participants were 76 students (15 male and 61 female) from the psychology faculty at Central Java, Indonesia. The data collection tool uses two scales to measure academic stress and positive mental health. Stress academic uses The academic stress inventory from Lin \& Chen (2009), which has been adapted into the Indonesian version. The measuring tool consists of 7 factors: teachers' stress, results stress, stress tests, studying in groups stress, peer stress, time management stress, and self-inflicted stress. A total of 34 statement items with Likert's five-point scale were used, ranging from 5 completely agree to 1 completely disagree. The reliability value of The Academic stress inventory scale is 0.93. to measure positive mental health using Lutz's Positive Mental Health Scale (PMH-scale), which has been tested for psychometric properties by Lukat et al. (2016) scalar invariance across samples and over time, high internal consistency, good retest-reliability, good convergent and discriminant validity as well as sensitivity to therapeutic change. Those are rated on a Likert scale from 1 (not true) to 4 (true) with nine total items. The reliability value of the PMH scale is 0.88 . Data analysis was carried out in two stages, the first was to examine the relationship between the dimensions of academic stress and positive mental health, the second stage was to perform a simple linear regression test for each dimension of academic stress as an independent variable with positive mental health as the dependent variable.

\section{Results and Discussion \\ Correlation Result}

The results of the correlation analysis between variables are shown in table 1. Intercorrelation among variables. Correlation results show that all variables are correlated with each other. The positive correlation values between stress dimensions were obtained from 0.364 to 0.676 . The magnitude of the correlation value is included in the low $(0.2-0.4)$ and medium $(0.4-0.70)$ categories. This positive correlation means that the higher the dimensions of academic stress, the higher the other dimensions of academic stress. While the negative correlation value between the dimensions of the academic stress variable and positive mental health starts from -0.269 to -0.579 . The magnitude of the correlation value is included in the low $(0.2-0.4)$ and medium $(0.4-0.70)$ categories. This negative correlation means that the higher the dimensions of academic stress (including teacher stress, result stress, Test stress, Studying in groups stress, Peer stress, Time management stress, Self-inflicted stress), the lower the Positive mental health. Table 1. It also shows the mean and SD values for each dimension of academic stress and Positive mental health. 
Table 2. Intercorrelation among variables

\begin{tabular}{|c|c|c|c|c|c|c|c|c|c|c|}
\hline & MEAN & SD & 1 & 2 & 3 & 4 & 5 & 6 & 7 & 8 \\
\hline \multirow[t]{2}{*}{ 1. TS } & 29.4 & 4.88 & - & & & & & & & \\
\hline & & & - & & & & & & & \\
\hline \multirow[t]{2}{*}{ 2. $R S$} & 16.6 & 3.59 & 0.506 & - & & & & & & \\
\hline & & & $<.001$ & - & & & & & & \\
\hline \multirow[t]{2}{*}{ 3. TS } & 13.9 & 3.19 & 0.638 & 0.552 & - & & & & & \\
\hline & & & $<.001$ & $<.001$ & - & & & & & \\
\hline \multirow[t]{2}{*}{ 4. $S G S$} & 17 & 4.68 & 0.521 & 0.408 & 0.645 & - & & & & \\
\hline & & & $<.001$ & $<.001$ & $<.001$ & - & & & & \\
\hline \multirow[t]{2}{*}{ 5. $P S$} & 12.8 & 2.7 & 0.42 & 0.409 & 0.459 & 0.45 & - & & & \\
\hline & & & $<.001$ & $<.001$ & $<.001$ & $<.001$ & - & & & \\
\hline \multirow[t]{2}{*}{ 6. TMS } & 9.79 & 2.48 & 0.599 & 0.579 & 0.619 & 0.66 & 0.458 & - & & \\
\hline & & & $<.001$ & $<.001$ & $<.001$ & $<.001$ & $<.001$ & - & & \\
\hline \multirow[t]{2}{*}{ 7. SIS } & 13.3 & 3.32 & 0.635 & 0.543 & 0.612 & 0.676 & 0.364 & 0.673 & - & \\
\hline & & & $<.001$ & $<.001$ & $<.001$ & $<.001$ & $<.001$ & $<.001$ & - & \\
\hline \multirow[t]{2}{*}{ 8. PMH } & 28.3 & 5.47 & -0.445 & -0.564 & -0.597 & -0.483 & -0.269 & -0.509 & -0.512 & 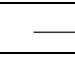 \\
\hline & & & $<.001$ & $<.001$ & $<.001$ & $<.001$ & 0.019 & $<.001$ & $<.001$ & 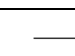 \\
\hline
\end{tabular}

Note: TS: teacher stress, RS: result stress, TS: Tests stress, SGS: Studying in groups stress, PS: Peer stress, TMS: Time management stress, SIS: Self-inflicted stress, PMH: Positive mental health

\section{Regression Analysis Result}

The linear regression data analysis results for each dimension of academic stress on positive mental health are shown in Table 2. Based on these results, information can be obtained that each dimension of academic stress significantly affects positive mental health. Teacher stress dimension has a value of 0.20 or $20 \%$, Result stress 0.32 or $32 \%$, test stress 0.36 or $36 \%$, Studying in groups stress 0.23 or $23 \%$, peer stress 0.07 or $7 \%$, time management stress 0.26 or $26 \%$ and Self- inflicted stress 0.26 or $26 \%$. It can be concluded that the stress test has the greatest contribution compared to other academic stress dimensions. Meanwhile, peer stress has the lowest contribution to positive mental health.

Table 2. linear regression dimension of academic stress to Positive mental health

\begin{tabular}{|l|l|l|r|r|r|r|}
\hline Dimension of Academic Stress & $\mathbf{R}$ & $\mathbf{R}^{2}$ & Estimate & SE & $\mathbf{t}$ & $\mathbf{p}$ \\
\hline Teacher stress & 0.45 & 0.20 & 42.934 & 3.472 & 12.37 & $<.001$ \\
\hline & & & -0.498 & 0.117 & -4.27 & $<.001$ \\
\hline Result stress & 0.56 & 0.32 & 42.569 & 2.485 & 17.13 & $<.001$ \\
\hline & & & -0.858 & 0.146 & -5.87 & $<.001$ \\
\hline Tests stress & 0.60 & 0.36 & 42.49 & 2.274 & 18.68 & $<.001$ \\
\hline & & & -1.02 & 0.16 & -6.4 & $<.001$ \\
\hline Studying in groups stress & 0.48 & 0.23 & 37.869 & 2.093 & 18.09 & $<.001$ \\
\hline & & & -0.564 & 0.119 & -4.74 & $<.001$ \\
\hline Peer stres & 0.27 & 0.07 & 35.239 & 2.949 & 11.95 & $<.001$ \\
\hline & & & -0.544 & 0.226 & -2.4 & 0.019 \\
\hline Time management stress & 0.51 & 0.26 & 39.29 & 2.227 & 17.64 & $<.001$ \\
\hline & & & -1.12 & 0.221 & -5.09 & $<.001$ \\
\hline Self-inflicted stress & 0.51 & 0.26 & 39.505 & 2.249 & 17.57 & $<.001$ \\
\hline & & & -0.843 & 0.164 & -5.13 & $<.001$ \\
\hline
\end{tabular}

As we all know, the pandemic has a major impact on aspects of life. The use of technology is increasing, so changes in new habits such as communication are one way for individuals to survive and fight culture shock (Wahyuningtyas et al., 2021). In the scope of education, academic stress occurs during online learning. The 
perceived burden causes more academic stress (Masitoh, 2020), in line with previous research, which said that additional learning was associated with academic stress (Pham, 2015).

The results of this study indicate that all dimensions of academic stress affect positive mental health. Our results support previous research that academic stress has a significant relationship with the mental health of high school students (Subramani \& Kadhiravan, 2017). Another study said that two-thirds or $66 \%$ of students reported feeling pressure from their parents for better academic performance to be the main cause. Academic stress positively correlated with students' mental problems (Deb et al., 2015). A study reported that a high study load and the need to prepare for the next day's class were factors of academic stress, making students more likely to commit suicide (Ruzhenkova et al., 2018). Some studies suggest that academic stress may increase during external events that trigger academic stress due to lack of control and loneliness related to social isolation (Mosanya, 2020). It is emphasized by the existence of the concept of lockdown related to restrictions in social contact as it is known to increase loneliness, stress, and a sense of vulnerability (Okruszek et al., 2020) so that students do not like online learning (Nugroho et al., 2020)

Our research has implications for distance learning using online learning, where students get more workloads than offline learning. Academic stress that occurs in students, which affects the positive mental health of students, is a problem that must be handled properly by educational institutions. One of them is by providing mental or academic health services. In addition, the workload felt by students may be applied more pleasantly so that students do not feel pressured to do it. This study has limitations in several respects, including relatively few participants and the lack of depth in the psychological dynamics in students who experience academic stress. Suggestions for further research is to use a better and in-depth research approach.

\section{Conclusions}

Mental health during a pandemic has received a lot of special attention by social science researchers. Students who undergo online lectures are important populations to study their mental health. This is done because students experience changes in learning methods from offline to online. The results of previous studies said that students experienced academic stress during online learning. Based on the results of this study, all dimensions of academic stress influence students' positive mental health. The results of this study can be used as a reference for universities to provide mental health services and other considerations in implementing online learning during the COVID-19 pandemic.

\section{References}

1. Aji, R. H. S. (2020). Dampak COVID-19 pada pendidikan di indonesia: Sekolah, keterampilan, dan proses pembelajaran. In Salam: Jurnal Sosial dan Budaya Syar-i.(7). amoito-konaweselatan.id. http://amoito-konaweselatan.id/desa/upload/dokumen/Dampak-Covid.pdf

2. Andiarna, F., \& Kusumawati, E. (2020). Pengaruh pembelajaran daring terhadap stres akademik mahasiswa selama pandemi Covid-19. Jurnal Psikologi, 16(2), 139-149.

3. Argaheni, N. B. (2020). Sistematik Review: Dampak Perkuliahan Daring Saat Pandemi COVID-19 Terhadap Mahasiswa Indonesia. PLACENTUM Jurnal Ilmiah Kesehatan Dan Aplikasinya, 8(2), 99108. https://doi.org/https://doi.org/10.20961/placentum.v8i2.43008

4. Barry, M. M. (2009). Addressing the Determinants of Positive Mental Health: Concepts, Evidence and Practice. International Journal of Mental Health Promotion, 11(3), 4-17. https://doi.org/10.1080/14623730.2009.9721788

5. Barseli, M., Ifdil, I., \& Nikmarijal, N. (2017). Konsep stres akademik siswa. Jurnal Konseling Dan Pendidikan, 5(3), 143-148. https://doi.org/https://doi.org/10.29210/119800

6. Calaguas, G. M. (2011). College academic stress: Differences along gender lines. Journal of Social and Development Sciences, 1(5), 194-201. https://doi.org/https://doi.org/10.22610/jsds.v1i5.644

7. Deb, S., Strodl, E., \& Sun, H. (2015). Academic stress, parental pressure, anxiety and mental health among Indian high school students. International Journal of Psychology and Behavioral Science, 5(1), 26-34.

8. Deroma, V. M., Leach, J. B., \& Leverett, J. P. (2009). The relationship between depression and college academic performance. College Student Journal, 43(2), 325-334. 
https://go.gale.com/ps/anonymous?id=GALE\%7CA201608594\&sid=googleScholar\&v=2.1\&it=r\&li nkaccess $=$ abs $\&$ issn $=01463934 \& p=A O N E \& s w=w$

9. Guo, Y. J., Wang, S. C., \& Johnson, V. (2011). College Students'stress Under Current Economic Downturn. College Student Journal, 45(3), 536-543. https://psycnet.apa.org/record/2011-24677-008

10. Herdian, H., \& Mildaeni, I. N. (2021). Academic Stress On Muslim Students In Indonesia: Study On Online Learning. Revista EDUCARE-UPEL-IPB-Segunda Nueva Etapa 2.0, 25(1), 224-239.

11. Jahoda, M. (1958). Current concepts of positive mental health. https://doi.org/https://doi.org/10.1037/11258-000

12. Lazarus, R. S., \& Folkman, S. (1984). Stress, appraisal, and coping. New York: Springer Pub. Co.

13. Lin, Y. M., \& Chen, F. S. (2009). Academic stress inventory of students at universities and colleges of technology. World Transactions on Engineering and Technology Education, 7(2), 157-162. http://www.wiete.com.au/journals/WTE\&TE/Pages/Vol.7, No.2 (2009)/8-03-Lin-Y.M.pdf

14. Lubis, H., Ramadhani, A., \& Rasyid, M. (2021). Stres akademik mahasiswa dalam melaksanakan kuliah daring selama masa pandemi Covid 19. Jurnal Psikologi, 10(1), 31-39.

15. Lukat, J., Margraf, J., Lutz, R., van der Veld, W. M., \& Becker, E. S. (2016). Psychometric properties of the positive mental health scale (PMH-scale). BMC Psychology, 4(1), 1-14.

16. Masitoh, A. (2020). Strategi koping siswa dalam menghadapi stres akademik di era pandemi Covid19. Academica: Journal of Multidisciplinary Studies, 4(2), 185-198.

17. Moawad, R. A. (2020). Online learning during the COVID-19 pandemic and academic stress in university students. Revista Românească Pentru Educaţie Multidimensională, 12(1 Sup2), 100-107.

18. Mosanya, M. (2020). Buffering Academic Stress during the COVID-19 Pandemic Related Social Isolation: Grit and Growth Mindset as Protective Factors against the Impact of Loneliness. International Journal of Applied Positive Psychology. https://doi.org/https://doi.org/10.1007/s41042020-00043-7

19. Nasution, D. A. D., Erlina, E., \& Muda, I. (2020). Dampak pandemi Covid-19 terhadap perekonomian Indonesia. Jurnal Benefita, 5(2), 212-224. https://doi.org/10.22216/jbe.v5i2.5313

20. Nugroho, R. A., Basari, A., Suryaningtyas, V. W., \& Cahyono, S. P. (2020). University students' perception of online learning in Covid-19 pandemic: A case study in a translation course. 2020 International Seminar on Application for Technology of Information and Communication (ISemantic), 225-231.

21. Nurdin, N., \& Anhusadar, L. (2020). Efektivitas Pembelajaran Online Pendidik PAUD di Tengah Pandemi Covid 19. Jurnal Obsesi: Jurnal Pendidikan Anak Usia Dini, 5(1), 686. https://doi.org/10.31004/obsesi.v5i1.699

22. Okruszek, L., Aniszewska-Stańczuk, A., Piejka, A., Wisniewska, M., \& Zurek, K. (2020). Safe but lonely? Loneliness, mental health symptoms and COVID-19. Frontiers in Psychology, 11. https://doi.org/10.3389/fpsyg.2020.579181

23. Pham, T. T. B. (2015). Study burden, academic stress and mental health among high school students in Vietnam. Queensland University of Technology.

24. Ruzhenkova, V. V, Ruzhenkov, V. A., Lukyantseva, I. S., \& Anisimova, N. A. (2018). Academic stress and its effect on medical students' mental health status.

25. Sipayung, R., Sihotang, D. O., \& Batu, J. S. L. (2021). Persepsi Guru Terhadap Efektivitas Pembelajaran Online Di Masa Pandemi COVID-19. Jurnal Ilmiah Aquinas, 4(2), 311-321.

26. Subramani, C., \& Kadhiravan, S. (2017). Academic stress and mental health among high school students. Indian Journal of Applied Research, 7(5), 404-406.

27. Sugihamretha, I. D. G. (2020). Respon Kebijakan: Mitigasi Dampak Wabah Covid-19 Pada Sektor Pariwisata. Jurnal Perencanaan Pembangunan: The Indonesian Journal of Development Planning. https://doi.org/10.36574/jpp.v4i2.113

28. Syahrial, S. (2020). Dampak COVID-19 terhadap Tenaga Kerja di Indonesia. Jurnal Ners, 4(2), 2129. https://journal.universitaspahlawan.ac.id/index.php/ners/article/view/1022/842

29. Ulya, H. N. (2020). Alternatif Strategi Penanganan Dampak Ekonomi Covid-19 Pemerintah Daerah Jawa Timur Pada Kawasan Agropolitan. El-Barka: Journal of Islamic Economics and Business, 3(1), 220. https://doi.org/10.21154/elbarka.v3i1.2018

30. Wahyuningtyas, B. P., Sumbogo, T. A., Rusgowanto, F. H., Yunus, U., Willyarto, M. N., \& Cahyanto, I. P. (2021). Social Networking Application of International Students on Fighting Culture 
Shock During Pandemic. 2021 International Conference on Information Management and Technology (ICIMTech), 1, 712-717. https://doi.org/10.1109/ICIMTech53080.2021.9534936

31. World health organization. (2018). Mental health: strengthening our response. In Fact sheet $N^{\circ} 220$. https://www.who.int/en/news-room/fact-sheets/detail/mental-health-strengthening-our-response 